\title{
Entre Panamá, Pandora y otros Asteroides
}

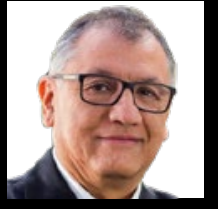

Eduardo Leyton Guerrero

Director de Carrera Contador

Público Auditor

Facultad de Economía y Negocios,

Universidad Alberto Hurtado
En términos astronómicos, la distancia que separa Panamá (Tierra) del planeta Pandora, de la película Avatar, es de 6 años luz; algo así como 5,676 1013 klms. Sin embargo, desde la perspectiva de los comprometedores documentos generados por la International Consortium of Investigative Journalists (ICIJ), conocidos como Panamá Papers el 2015 y Pandora Papers liberados el pasado 3 de octubre del 2021, en términos de contenidos, compromisos, acuerdos, responsabilidades, intenciones, principios y valores consignados en los mismos; parecieran ser que, ambos lugares idílicos y paradisiacos, efectivamente son limítrofes.

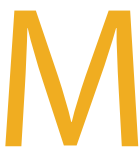
as allá del análisis geográfico y turístico que podamos realizar entre Panamá y Pandora, nos encontramos con coordenadas de comportamiento similares de lideres, artistas, deportistas, famosos y famosillos actuales que nos estremecen, nos cuestionan, nos irritan, nos entristecen y nos frustran como ciudadanos.

Lo que subyace a estos ejes, no necesariamente es una situación jurídica; aunque en cada país de origen de dichos actores podrían ser constitutivos de delito. Sin embargo, en mi opinión, este es un grave problema de actitud sombría y una predis- posición depredadora constante de sacar el máximo de ventajas a como de lugar, sin considerar sus efectos.

En el Reino Animal, para que opere la cadena alimenticia, este es un valor insoslayable entre sus miembros; pero en un mundo de humanos globalizado, hiper conectado y digital, los estándares de comportamiento son y deben ser distintos a los del siglo pasado y anteriores. Desde esa perspectiva, es absolutamente inadmisible estos patrones de conductas lóbregos.

Por cierto, la admiración por sus logros y éxitos, en sus distintos ámbitos, no está en cuestión. Pero cuando la naturaleza nos ha dotado de cualidades y atributos que sobresalen del resto, el estándar de honestidad, benevolencia y responsabilidad humana es y debe ser prístino.

En caso contrario, ¿en qué me diferencio de mi perro Newton, un animal doméstico cuyo salvajismo esta inerte? ¿cómo podemos exigirle al resto de los humanos menos afortunados de la naturaleza que, primero cumplan la ley y sobre aquello tengan actitudes incólumes e irreprochables?

Los afortunados tienen responsabilidades ineludibles con el prójimo. 


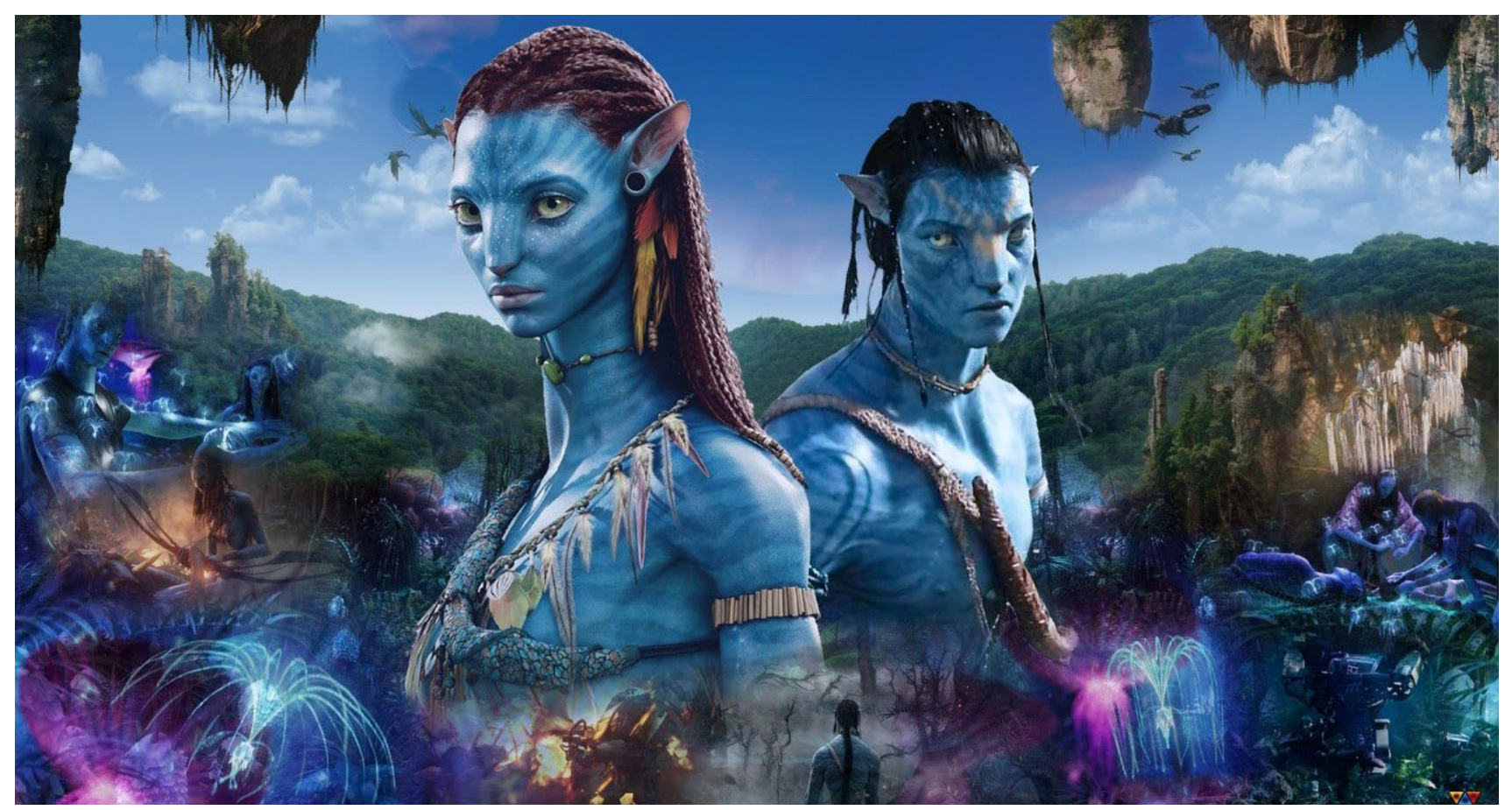

"¿Qué pasa en nuestro núcleo familiar?, ¿nuestros padres corrigen y enseñan a nuestros hijos para distinguir los colores divinos
de plantas y flora de Pandora (o de Panamá) y del planeta

\section{Honestidad?"}

Pero ¿qué otros actores que por acción o por omisión son partes de esta umbra y penumbra?

No es difícil entender que estos hechos sombríos no fueron por generación espontánea, ni producidos por la energía del vacío, como dirían un físico cuántico o un cosmólogo.

¡Hay más en esta cadena de eventos! Siendo simplistas, quizás podemos afirmar que la sociedad en su conjunto, en las distintas dimensiones y expresiones de ésta, son responsables.

Pero, no nos conformemos con esa afirmación. Tratemos de desmenuzar.

¿Dónde o en que dimensión del mundo de los negocios, nos afectó el daltonismo y perdimos la capacidad de distinguir claramente los colores de la deshonestidad? ¿Qué pasó con la industria bancaria? ¿qué rol tuvieron las entidades regulatorias y de fiscalización? ¿qué sucedió con la ética profesional de los intervinientes? ¿Qué nos sucedió como Contadores Públicos y Auditores?
Afortunadamente la prensa, una vez más, hizo su trabajo de nivelación.

El problema parece, y por cierto lo es, infinitamente más complejo, pero aun así identificable.

¿Qué pasa en nuestro núcleo familiar?, ¿nuestros padres corrigen y enseñan a nuestros hijos para distinguir los colores divinos de plantas y flora de Pandora (o de Panamá) y del planeta Honestidad?

¿Qué sucede en nuestra educación primaria, secundaria y finalmente universitaria? ¿Cómo regulamos los actos tendenciosos de nuestros alumnos? ¿Cuán responsables somos como formadores al retener a toda costa alumnos?

Cualquiera que analice los programas académicos universitarios, incluso de elite, podrá encontrar múltiples cursos de ética profesional o ética de los negocios o deontología. Pero, en definitiva y en la práctica, ¿cómo hemos construido nuestra sociedad? ¿Qué tan equitativa es? Los índices de desarrollo humano, de corrupción, de felicidad, entre otros, algo nos advierten. A propósito, convengamos que es atemporal, casi a los 70 años, pedirle por sentencia judicial a un emprendedor asistir a clases de ética. $O$, en otro caso, hacer cumplir la condena de privación de libertad en su fundo en el sur de Chile. iSencillamente irrisorio y tarde! El árbol de Na'vi: Vitraya Ramunong creció patituerto.

¿Qué les sucedió a nuestras instituciones verticalizadas, incluso algunas de ellas de milenarias?

En términos mas específicos, alguien puede argumentar: "no es delito, la ley no lo tipifica". Pero el argumento de fondo no es un tema jurídico, es deontológico. Incluso existiendo la ley, el compromiso básico de un sistema judicial justo, es que sus miembros apliquen la ley.

Hay muchos eslabones en esta cadena. Pero son reconocibles.

Aun hay voces que replican:" necesitamos más fiscalizadores". Tengo el profundo convencimiento que no. Lo que se requiere es honestidad.

En fin, ¿usted hace saber que recibió dinero demás?

Yo sí, acabo de hacerlo con un monto considerable. 